International Journal of Business Management and Economic Review

Vol. 4, No. 05; 2021

ISSN: 2581-4664

\title{
THE ROLE OF RISK-TAKING MODERATION ON THE PERFORMANCE OF SMALL AND MEDIUM ENTERPRISES IN THE PANDEMIC ERA
}

\author{
SayidIrwan, Syarifah Hudayah, Irwansyah, Gusti Noorlita Achmad \\ Faculty of Economics and Business,Mulawarman University, Samarinda, Indonesia
}

http://doi.org/10.35409/IJBMER.2021.3311

\begin{abstract}
During pandemics and restrictions on social and economic activities of the community, the role of small and medium enterprises (SMEs) contributes tremendously to the economy. This study analyzed the Role of Risk-Taking Moderation by small and medium-sized enterprises on the relationship of Online Marketing and Offline Marketing to Small and Medium Enterprises (SMEs). Using Structural Equation Modeling (SEM), the results of the analysis: Online Marketing and Offline Marketing is positively, significantly correlated to the Performance of Small and Medium Enterprises. However, the level of signification is stronger than Online Marketing. The weakening role of moderation from risk-taking to offline marketing and online marketing relationships to the performance of small and medium-sized businesses. It was proven during the Pandemic that prudence in risk-taking could save small and medium-sized business entrepreneurs from surviving.
\end{abstract}

Keyword: Performance Small and Medium Enterprises (SMEs), Online Marketing, Offline Marketing, Structural Equation Modeling.

\section{INTRODUCTION}

The continuity of the business of small and medium enterprises (SMEs) cannot separate from the Performance of SMEs themselves. The phenomenon in the community is that business existence remains amid uncertain economic turmoil and in the era of the Covid-19 Pandemic that causes limited mobility of SMEs entrepreneurs in marketing their products.

Small and medium enterprises (SMEs) play an essential role in all economies around the world. SMEs are responsible for creating jobs, alleviating poverty, contributing to innovation and a country's gross domestic product(Cant \& Wiid, 2016).

SMEs' performance is the ability to adapt significantly in risk-taking in an atmosphere full of uncertainty and utilize IoT (Internet of things). SME entrepreneurs struggle to earn income and profits still.

Risk-taking is an entrepreneurial orientation that reflects calculated and manageable risks. Risktaking is a dominant attribute of entrepreneurship because the higher the risk-taking orientation, the higher the profitability and growth of the company(Wambugu et al., 2015).According to (Games \&Rendi 2019) research, Taking risks is a clear growth path to improve SMEs' financial performance. 
International Journal of Business Management and Economic Review

Vol. 4, No. 05; 2021

ISSN: 2581-4664

\section{LITERATURE REVIEW}

According to(USAID 2019), the Theory of Change (ToC) can apply in SMEs: Theory of Market Interconnectedness Change; Business Management Change Theory; Theory of Changes in Financial Access; Theory of Business Registration and Tax; Theory of Innovation Change.

Research results (Dzisi \& Ofosu, 2014)revealed that offline marketing is positively correlated and significant to the Performance of SMEs. The same thing conveyed by (H et al., 2015) is that marketing in SMEs still uses traditional methods such as print media and hard-selling although improving SME Performance. SME owners should consider the findings and seek to introduce SME-specific marketing practices to achieve higher volume and sales growth. SME marketing practices need to be adapted based on findings to ensure SME marketing practices are compatible with current digital approaches.

According to(Öztamur \& Karakadılar, 2014), SMEs' common problems are related to using formal language during customer communication and creating less rich unattractive content to grab their customers' attention in their social media activities. According to (Eid \& El-Gohary, 2013), Online Marketing, or marketing through social media, positively influences SME presales activities, after-sales activities, marketing performance, and marketing effectiveness. Research conducted by (Manley 2015)By comparing traditional(Offline) marketing with internet (Online)or E-Marketing. The internet revolution has changed how many organizations conduct business in today's market environment and has specifically changed how companies market products to consumers. E-marketingallows marketers to reach a broader target market than traditional methods and substantially reduce marketing costs, meaning the difference between success or failure in small and medium-sized enterprises (SMEs). By providing a comparative analysis between the use of traditional tools and electronic marketing. SME owners have no preference in using traditional tools or e-marketing, with the majority preferring to use both. However, most marketing tools are used and receiving the most effective ratings according to SME owners direct to electronic marketing tools.

Risk-taking affects the Performance of SMEs. According to the study results by (Kitigin 2017), there is a strong positive correlation between risk-taking and the business performance of SMEs.(Pratono 2018)confirms the positive impact of risk-taking behavior on a company's performance and identifies that risk-taking behavior on a company's performance is more effective on low information technology turbulence than high information technology turbulence. Different research results conducted by(Le Roux \& Bengesi, 2014) show a significant negative relationship between risk-taking and SME performance.

In SMEs, the effectiveness and implementation of enterprise risk management systems (ERM)areminor in research literacy. Most small and medium-sized enterprises (SMEs) are family companies, where family dynamics influence risky behavior. The research results(Glowka et al., 2020) show that ERM implementation has no direct effect on SMEs' financial performance.According to(Yakob et al., 2019), The influence of Enterprise Risk Management (ERM) on the Performance of Small and Medium Enterprises (SME) shows that ERM has a significant effect on the performance of the company. However, only one element of ERM is the determination of goals that significantly affect SMEs' performance.

\section{CONCEPTUAL FRAMEWORK AND RESEARCH HYPOTHESIS}

The Conceptual Framework of the Research Model can see in Figure 1. 


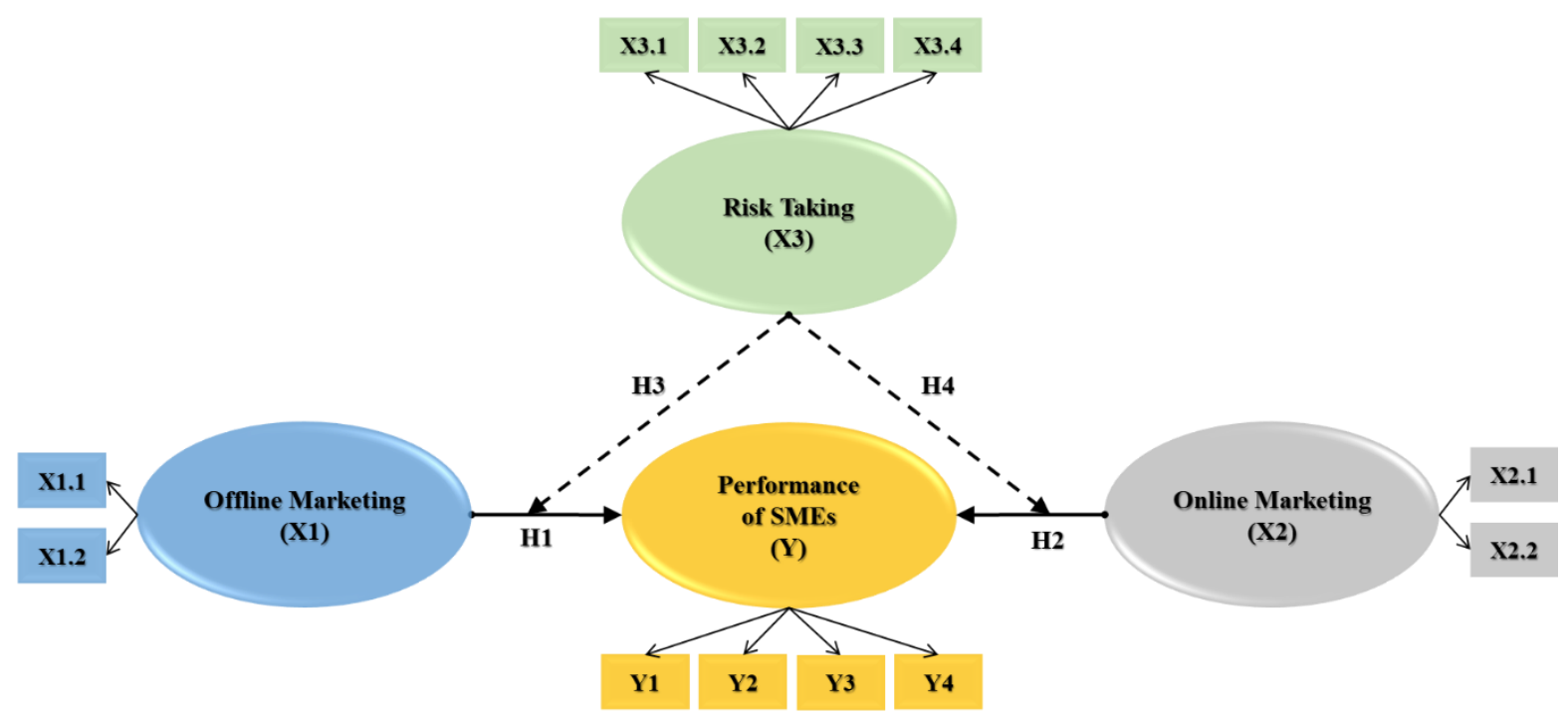

Figure 1. Conceptual Framework and Research Hypothesis

Description of Notation:

Offline Marketing (X1)

X1.1: We sell our products with direct sales transactions by meeting with consumers.

X1.2: We sell our products by serving consumers in areas close to where we sell face-to-face.

Online Marketing (X2)

$\mathrm{X} 2.1$ : We sell our products by selling transactions using internetfacilities.

X2.2: We sell our products by serving consumers in distant areas where we sell, with Social Media facilities.

Risk-Taking (X3)

X3.1: We tend to take on low-risk, and regular, projects with average small profit rates.

$\mathrm{X} 3.2$ : We are cautious of the business environment and cautious of behavior.

$\mathrm{X} 3.3$ :We would rather wait and see to minimize losses.

X3.4: We do not like to take chances in an effort; we like to be morecareful.

Performance of SMEs (Y)

Y1: Our customers are increasing every month.

Y2: Our turnover is constantly increasing.

Y3: Our marketing is constantly evolving and expanding out of the area.

Y4: We are constantly increasing the number of employees. 
International Journal of Business Management and Economic Review

Vol. 4, No. 05; 2021

ISSN: 2581-4664

Hypothesis 1 (H1): Offline Marketing relates Positively and Significantly to the Performance of SMEs.

Hypothesis 2 (H2): Online Marketing relates Positively and Significantly to the Performance of SMEs.

Hypothesis $3(\mathrm{H} 3)$ : There is a weakening role of Risk-Taking moderation in the relationship of Offline Marketing with SMEs Performance.

Hypothesis 4 (H4): There is a weakening role in Risk-Taking moderation in the relationship of Marketing Online with SMEs Performance.

\section{STRUCTURAL EQUATION MODELING (SEM)}

Structural Equation Modeling (SEM) can see in Figure 2.

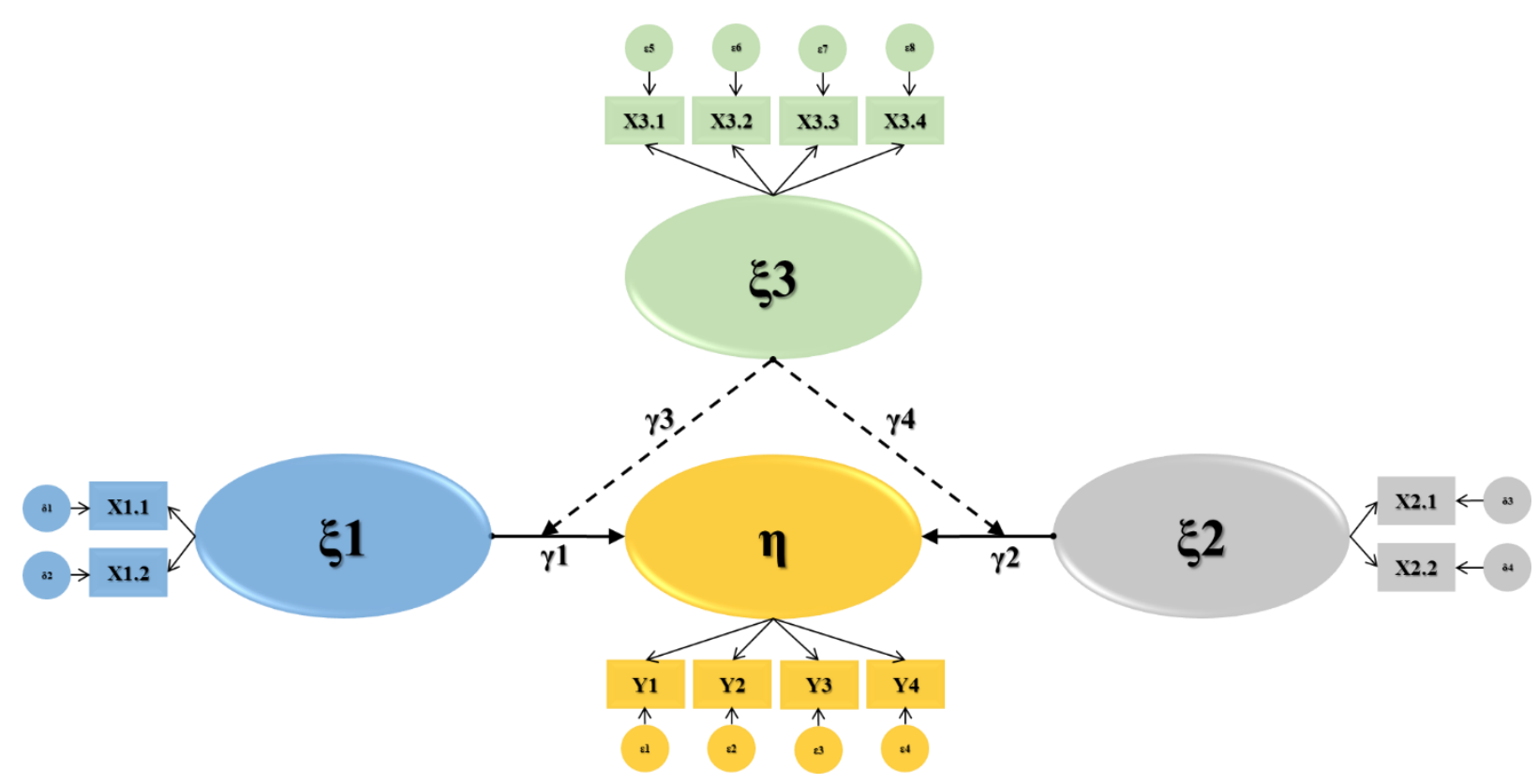

Figure 2. Structural Equation Modeling (SEM)

Notations used in Structural Equation Modeling (SEM):

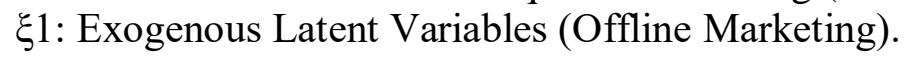

द2: Exogenous Latent Variables (Online Marketing).

33: Exogenous Latent Variables (Risk-Taking).

$\eta$ : Endogenous Latent Variables (Performance of SMEs).

$\delta$ : Measurement error on the manifest variable for Exogenous latent variable.

$\varepsilon$ : Measurement error on the manifest variable for latent variable Endogene.

$\gamma$ : Coefficient of influence of exogenous variables on endogenous variables.

Outer Model Equation: 


\section{Offline Marketing(X1) or ( $\xi 1)$ :}

$\mathrm{X}_{1.1}=\lambda_{\mathrm{X} 1.1} \xi_{1}+\delta_{1}$

$\mathrm{X}_{1.2}=\lambda_{\mathrm{X} 1.2} \xi_{2}+\delta_{2}$

Online Marketing(X2) or ( $\xi 2)$ :

$\mathrm{X}_{21}=\lambda \times 2.1 \xi_{2}+\delta_{3}$

$\mathrm{X}_{22}=\lambda \times 2.2 \xi_{2}+\delta_{4}$

Risk-Taking (X3) or ( $\xi 3)$ :

$\mathrm{X}_{3.1}=\lambda_{\mathrm{X} 3.1} \xi_{3}+\delta_{5}$

$\mathrm{X}_{3.2}=\lambda_{\mathrm{X} 3.2} \xi_{3}+\delta_{6}$

$\mathrm{X}_{3.3}=\lambda_{\mathrm{X} 3.3} \xi_{3}+\delta_{7}$

$\mathrm{X}_{3.4}=\lambda_{\mathrm{X} 3.4} \xi_{3}+\delta_{8}$

Performance of SMEs $(Y)$ or $(\eta)$ :

$\mathrm{Y}_{1}=\lambda_{\mathrm{Y} 1} \xi_{3}+\varepsilon_{1}$

$\mathrm{Y}_{2}=\lambda_{\mathrm{Y} 2} \xi_{3}+\varepsilon_{2}$

$\mathrm{Y}_{3}=\lambda_{Y_{3}} \xi_{3}+\varepsilon_{3}$

$\mathrm{Y}_{4}=\lambda_{\mathrm{Y} 4} \xi_{3}+\varepsilon_{4}$

Inner Model Equation:

Performance of SMEs (Y) or $(\eta): \gamma_{1} \xi_{1}+\gamma_{2} \xi_{2}+\gamma_{3} \xi_{1} * \xi_{3}+\gamma_{4} \xi_{2} * \xi_{3}+\xi 1$

\section{METHODS}

This research method is Explanatory Research, which analyzes 4 (four) hypotheses. Structural Equation Modeling (SEM) proves the relationships between the latent variables test. Respondents are Small, and Medium Enterprises (SMEs) domiciled in Samarinda City, East Kalimantan Province, Indonesia. The small and Medium Enterprise Entrepreneurs (SMEs) population is still actively trying as many as 715 entrepreneurs. The sample number of studies is 496 SMEs Entrepreneurs. In multivariate analysis already considers the relationship between variables.

Using variance-based and factor-based structural equation models (SEM), using the least-squares and factor-based methods. (Kock, 2015b)(Kock, 2015a). There is a ten model fit and quality index(Kock, 2010)(Kock, 2014)(Kock, 2015c), as follows (refer to Table 1): 
International Journal of Business Management and Economic Review

Vol. 4, No. 05; 2021

ISSN: 2581-4664

Table 1. Model fit and quality index

\begin{tabular}{|l|l|l|}
\hline No & Model fit \& Quality index & Criteria Fit \\
\hline 1 & Average Path Coefficient (APC) & $\mathrm{p}<0.001$ \\
\hline 2 & Average R-squared (ARS) & $\mathrm{p}<0.001$ \\
\hline 3 & Average Adjusted R-squared (AARS) & $\mathrm{p}<0.001$ \\
\hline 4 & $\begin{array}{l}\text { Average block Variance Inflation Factor } \\
\text { (AVIF) }\end{array}$ & Acceptable if $\leq 5$ \\
\cline { 3 - 3 } 5 & Ideally $\leq 3.3$ \\
\hline \multirow{2}{*}{6} & \multirow{2}{*}{ Tenenhauge Full Collinearity VIF (AFVIF) } & Acceptable if $\leq 5$ \\
\cline { 3 - 3 } & & Ideally $\leq 3.3$ \\
\hline 7 & Simpson's paradox ratio (SPR) & Small $\geq 0.1$ \\
\cline { 3 - 3 } & Medium $\geq 0.25$ \\
\hline 8 & R-squared contribution ratio (RSCR) & Large $\geq 0.36$ \\
\cline { 3 - 3 } & Scceptable if $\geq 0.7$ \\
\hline 9 & Statistical suppression ratio (SSR) & Acceptable if $\geq 0.9$ \\
\hline 10 & $\begin{array}{l}\text { Nonlinear- bivariate causality- direction ratio } \\
\text { (NLBCDR) }\end{array}$ & Adeally $=1$ \\
\hline
\end{tabular}

\section{RESULTS ANDDISCUSSION}

Table 2. Composite reliability coefficients, Cronbach's alpha coefficients, Average variances extracted (AVE)

\begin{tabular}{|l|c|c|c|}
\hline Latent Variables & $\begin{array}{c}\text { Composite } \\
\text { reliability } \\
\text { coefficients }\end{array}$ & $\begin{array}{c}\text { Cronbach's alpha } \\
\text { coefficients }\end{array}$ & $\begin{array}{c}\text { Average variances } \\
\text { extracted (AVE) }\end{array}$ \\
\hline Offline Marketing (X1) & 0.911 & 0.805 & 0.837 \\
\hline Online Marketing (X2) & 0.954 & 0.903 & 0.912 \\
\hline Risk-Taking (X3) & 0.806 & 0.676 & 0.515 \\
\hline Performance of SMEs (Y) & 0.930 & 0.900 & 0.770 \\
\hline
\end{tabular}


International Journal of Business Management and Economic Review

Vol. 4, No. 05; 2021

ISSN: 2581-4664

Table 3. Analysis Results Model fit and quality index

\begin{tabular}{|c|c|c|c|c|}
\hline No & $\begin{array}{l}\text { Model fit \& Quality } \\
\text { index }\end{array}$ & Criteria Fit & $\begin{array}{l}\text { Analysis } \\
\text { results }\end{array}$ & Remarks \\
\hline 1 & $\begin{array}{l}\text { Average Path } \\
\text { Coefficient (APC) }\end{array}$ & $\mathrm{p}<0.001$ & $\begin{array}{l}0.259 \\
p<0.001\end{array}$ & $\begin{array}{l}\text { Good } \\
\text { Significant }\end{array}$ \\
\hline 2 & $\begin{array}{l}\text { Average R-squared } \\
\text { (ARS) }\end{array}$ & $\mathrm{p}<0.001$ & $\begin{array}{l}0.492 \\
p<0.001\end{array}$ & $\begin{array}{l}\text { Good } \\
\text { Significant }\end{array}$ \\
\hline 3 & $\begin{array}{l}\text { Average Adjusted R- } \\
\text { squared (AARS) }\end{array}$ & $\mathrm{p}<0.001$ & $\begin{array}{l}0.487 \\
p<0.001\end{array}$ & $\begin{array}{l}\text { Good } \\
\text { Significant }\end{array}$ \\
\hline \multirow[b]{2}{*}{4} & \multirow{2}{*}{$\begin{array}{l}\text { Average block } \\
\text { Variance Inflation } \\
\text { Factor (AVIF) }\end{array}$} & Acceptable if $\leq 5$ & & \\
\hline & & Ideally $\leq 3.3$ & 1.187 & Ideal \\
\hline \multirow[b]{2}{*}{5} & \multirow{2}{*}{$\begin{array}{l}\text { Average Full } \\
\text { Collinearity VIF } \\
\text { (AFVIF) }\end{array}$} & Acceptable if $\leq 5$ & & \\
\hline & & Ideally $\leq 3.3$ & 2.436 & Ideal \\
\hline \multirow{3}{*}{6} & \multirow{3}{*}{ TenenhausGoF (GoF) } & Small $\geq 0.1$ & & \\
\hline & & Medium $\geq 0.25$ & & \\
\hline & & Large $\geq 0.36$ & 0.579 & Large \\
\hline \multirow{2}{*}{7} & \multirow{2}{*}{$\begin{array}{l}\text { Simpson's paradox ratio } \\
\text { (SPR) }\end{array}$} & Acceptable if $\geq 0.7$ & 1 & Ideal \\
\hline & & Ideally $=1$ & & \\
\hline \multirow{2}{*}{8} & \multirow{2}{*}{$\begin{array}{l}\text { R-squared contribution } \\
\text { ratio (RSCR) }\end{array}$} & Acceptable if $\geq 0.9$ & 1 & Ideal \\
\hline & & Ideally $=1$ & 1 & Ideal \\
\hline 9 & $\begin{array}{l}\text { Statistical suppression } \\
\text { ratio (SSR) }\end{array}$ & Acceptable if $\geq 0.7$ & 1 & Accepted \\
\hline 10 & $\begin{array}{l}\text { Nonlinear- bivariate } \\
\text { causality- direction } \\
\text { ratio (NLBCDR) }\end{array}$ & Acceptable if $\geq 0.7$ & 0.750 & Accepted \\
\hline
\end{tabular}

Table 4. R-squared coefficients, Adjusted R-squared coefficients, Q-squared coefficients

\begin{tabular}{|l|c|c|c|}
\hline Latent Variables & $\begin{array}{c}\text { R-squared } \\
\text { coefficients }\end{array}$ & $\begin{array}{c}\text { Adjusted R-squared } \\
\text { coefficients }\end{array}$ & $\begin{array}{c}\text { Q-squared } \\
\text { coefficients }\end{array}$ \\
\hline Performance of SMEs (Y) & 0.492 & 0.487 & 0.486 \\
\hline
\end{tabular}


International Journal of Business Management and Economic Review

Vol. 4, No. 05; 2021

ISSN: 2581-4664

Results of 1st Hypothesis Analysis (H1)

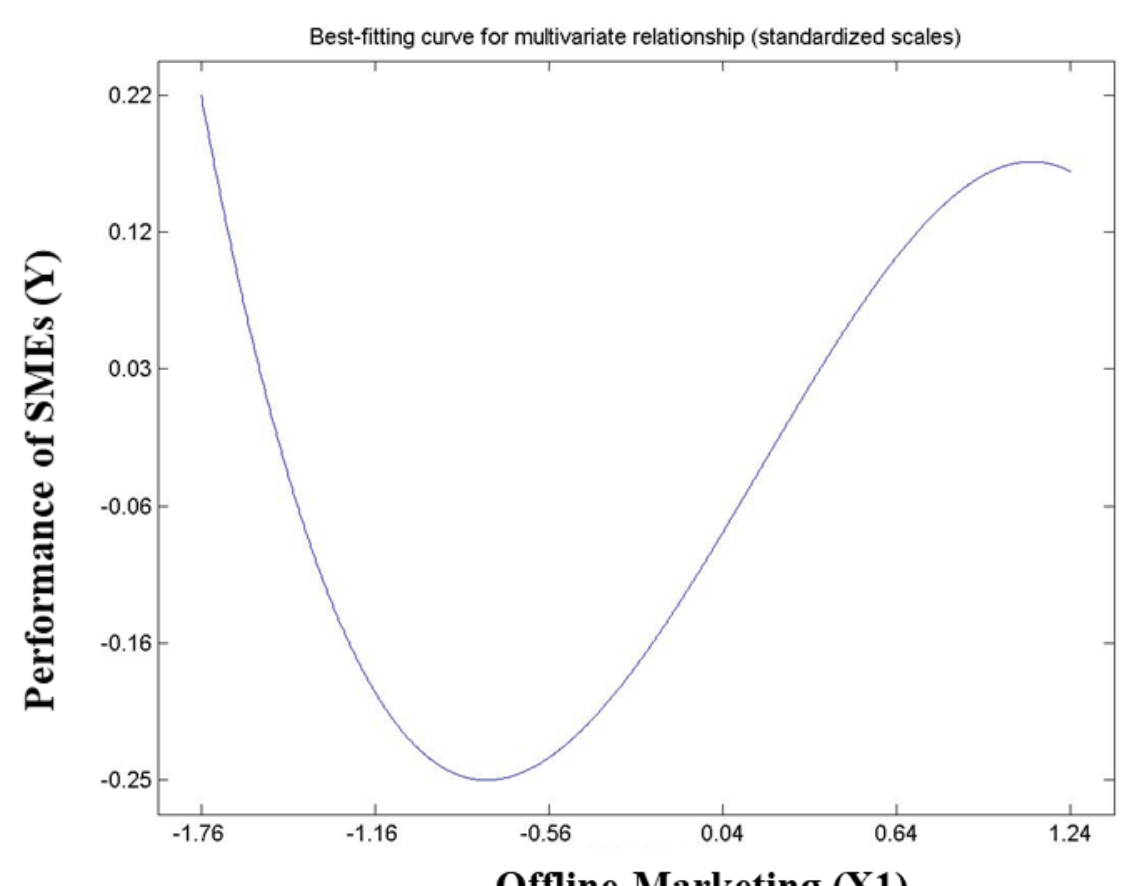

Figure 3. The best-fitting curve for a multivariate relationship between Offline Marketing (X1)with Performance of SMEs (Y)

The relationship between Offline Marketing (X1) to Performance of SMEs (Y)is Positive ( $\beta=$ $0.165)$ and Significant $(\mathrm{p}<0.001)$. This analysis proves statically that Offline Marketing (X1) can still improve SMEs Performance (Y). In figure 3, it seemsthat the early stages of Offline Marketing (X1) results in a decrease in SMEs Performance (Y), but in the later stages, it seems that Offline Marketing (X1) causes an increase in SMEs Performance (Y). 
International Journal of Business Management and Economic Review

Vol. 4, No. 05; 2021

ISSN: 2581-4664

Results of the Second Hypothesis Analysis (H2)

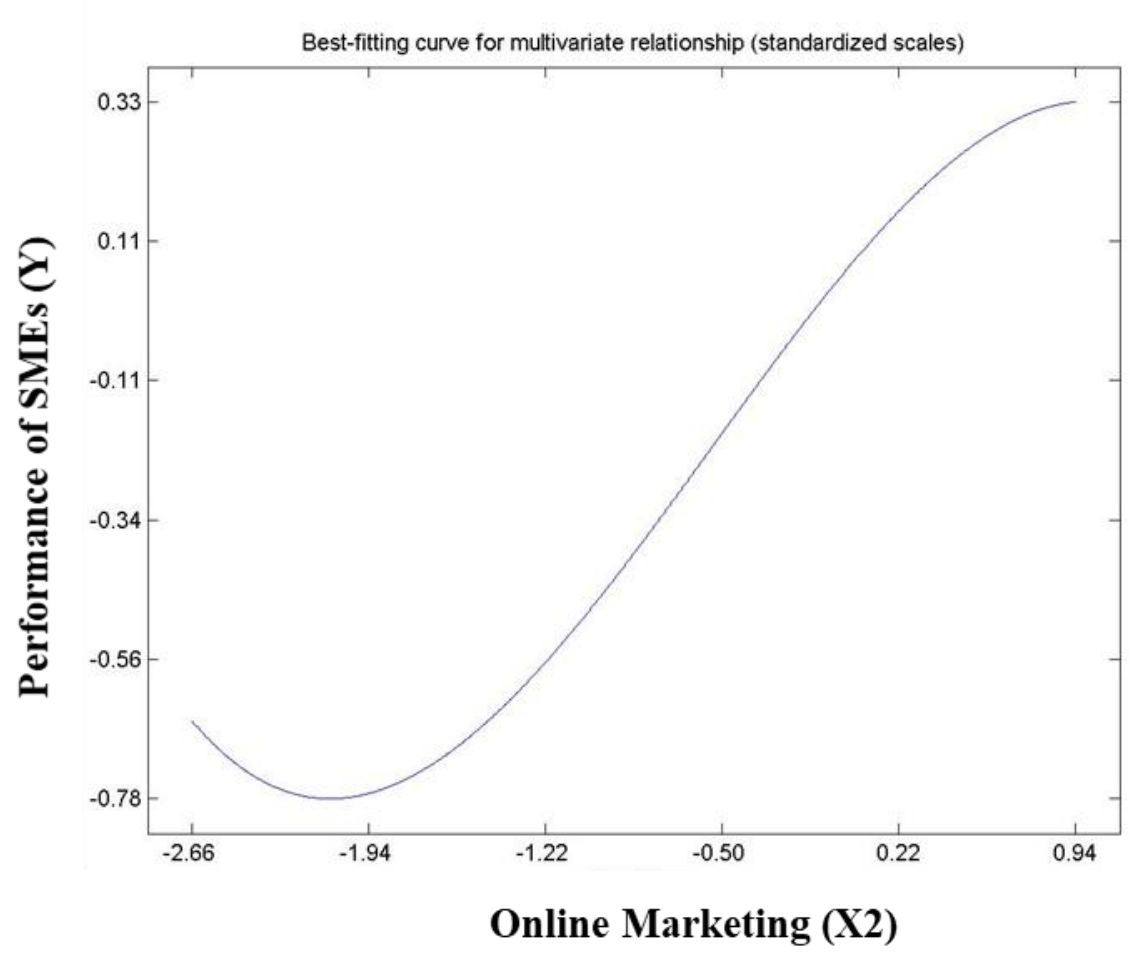

Figure 4. The best-fitting curve for a multivariate relationship between Online Marketing (X2) with Performance of SMEs (Y)

The relationship between Online Marketing (X2) to Performance of SMEs (Y)modeled this study: first, the relationship is positive and significant $(\beta=0.365, \mathrm{p}<0.001)$. In figure 3 , it seems that Online Marketing (X2) led to improvements in SMEs' performance (Y); this proves statically that Online Marketing (X2) contributes significantly to the improvement of SMEs Performance (Y). 
International Journal of Business Management and Economic Review

Vol. 4, No. 05; 2021

ISSN: 2581-4664

\section{Results of the Third Hypothesis Analysis (H3)}

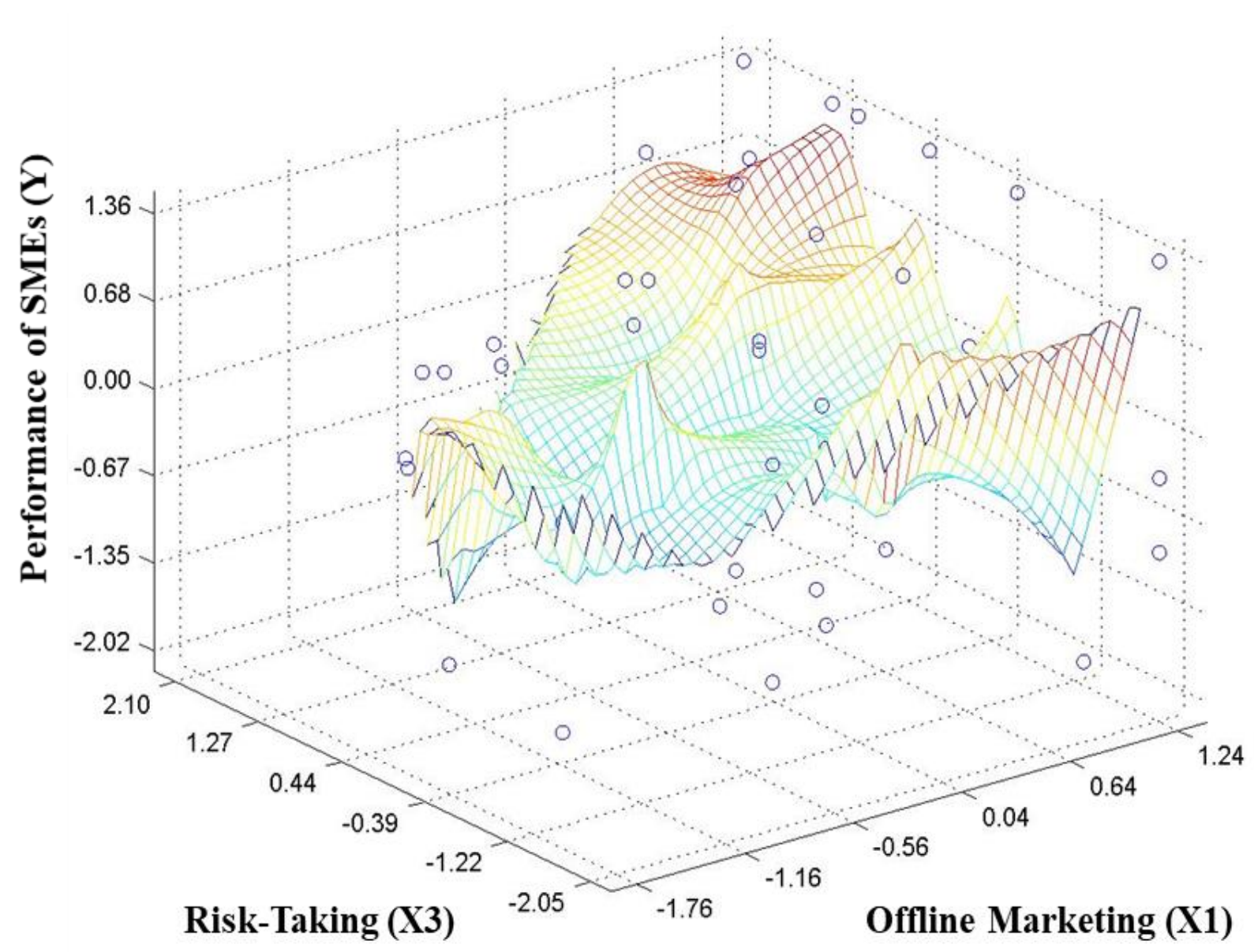

Figure 5.Rocky 3D graph for moderating effect with data points. The role of Risk-Taking Moderation (X3) has a relationship between Offline Marketing (X1) and the Performance of SMEs (Y)

In figure 5, The Moderating Role of Risk-Taking (X3) from the results of the analysis is significant and weakens the relationship between Offline Marketing (X1) and SMEs Performance (Y).

\section{Fourth Hypothesis Analysis Results (H4)}


International Journal of Business Management and Economic Review

Vol. 4, No. 05; 2021

ISSN: 2581-4664

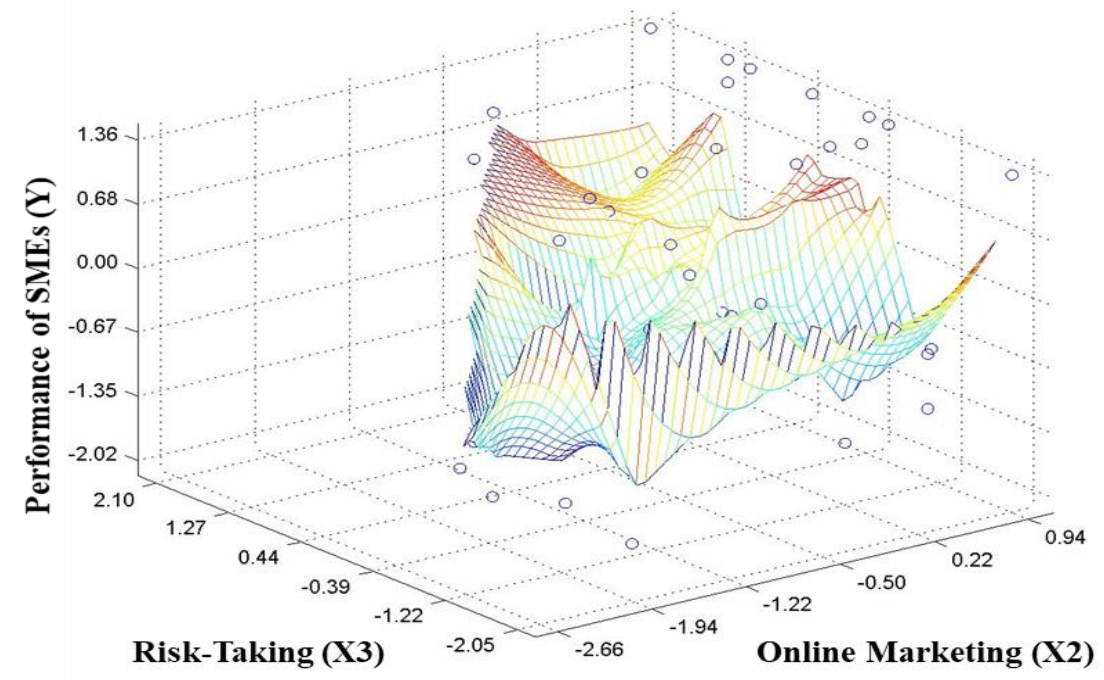

Figure 6.Rocky 3D graph for moderating effect with data points. The role of Risk-Taking Moderation (X3) has a relationship between Online Marketing (X2) and the Performance of SMEs (Y)

The same is true of the Role of Risk-Taking Moderation (X3) in the relationship of Online Marketing (X2) with SMEs Performance (Y). In Figure 6, it is seen from the results of the analysis that the Role of Risk-Taking Moderation (X3) weakens the relationship of Online Marketing (X2) with Performance SMEs (Y). The role of risk-taking moderation (X3) weakens the relationship of Offline Marketing (X1) and Online Marketing (X2) to SMEs Performance (Y).

\section{CONCLUSION}

The overall conclusions of the results of this analysis are:

In this pandemic era, offline marketing still needs it is due to the nature of the Samarinda city community that still upholds a culture of high social interaction. People still interact physically, one with each other, including buying products peddled by small and medium enterprises (SMEs).

From the results of the analysis, Online Marketing shows a more significant contribution compared to Offline Marketing. It is understandable that in the pandemic era, people have become accustomed to buying and selling using social media facilities and maintaining their health from contracting the coronavirus.

Prudent risk-taking can understand as a strategy to maintain the continuity of efforts of SMEs. Amid an atmosphere full of uncertainty, it is wise to be more careful, be safe, and maintain the performance of SMEs. 


\section{International Journal of Business Management and Economic Review}

Vol. 4, No. 05; 2021

ISSN: 2581-4664

The Theory of Change (ToC) proves to occur in society in general and SMEs Entrepreneurs, mainly to survive and maintain their business entrepreneurs' continuity.

Making a change is not a bad thing. Making Change is an inevitability not to be run over from the times and a hostile environment.

\section{REFERENCES}

Cant, M. C., \& Wiid, J. A. (2016). The use of traditional marketing tools by SMEs in an emerging economy: A South African perspective. Problems and Perspectives in Management. https://doi.org/10.21511/ppm.14(1).2016.07

Dzisi, S., \& Ofosu, D. (2014). Marketing Strategies and the Performance of SMEs in Ghana. European Journal of Business and Management.

Eid, R., \& El-Gohary, H. (2013). The impact of E-marketing uses on small business enterprises' marketing success. Service Industries Journal. https://doi.org/10.1080/02642069.2011.594878

Games, D., \& Rendi, R. P. (2019). The effects of knowledge management and risk-taking on SME financial Performance in creative industries in an emerging market: the mediating effect of innovation outcomes. Journal of Global Entrepreneurship Research. https://doi.org/10.1186/s40497-019-0167-1

Glowka, G., Kallmünzer, A., \& Zehrer, A. (2020). Enterprise risk management in small and medium family enterprises: the role of family involvement and CEO tenure. International Entrepreneurship and Management Journal. https://doi.org/10.1007/s11365-020-00682-x

H, A. R., K, A. W., \& A, S. (2015). The Shift from Traditional Marketing to Entrepreneurial Marketing Practices: A Literature Review. Business and Management Studies. https://doi.org/10.11114/bms.v1i2.993

Kitigin, B. (2017). Relationship between Risk-Taking and Business Performance among Small and Medium Enterprises in Eldoret Town, Kenya. International Journal of Business and Management Review, 5(7), 52-59.

Kock, N. (2010). Regressing WarpPLS in e-collaboration studies: An overview of five main analysis steps. International Journal of E-Collaboration, 6(4), 1-11. https://doi.org/10.4018/jec.2010100101

Kock, N. (2014). Advanced Mediating Effects Tests, Multi-Group Analyses, and Measurement Model Assessments in PLS-Based SEM. International Journal of E-Collaboration, 10(1), 1-13. https://doi.org/10.4018/ijec.2014010101

Kock, N. (2015a). A note on how to conduct a factor-based PLS-SEM analysis. International Journal of E-Collaboration, 11(3), 1-9. https://doi.org/10.4018/ijec.2015070101 
Vol. 4, No. 05; 2021

ISSN: 2581-4664

Kock, N. (2015b). PLS-based SEM Algorithms: The Good Neighbor Assumption, Collinearity, and Nonlinearity. Information Management and Business Review, 7(2), 113-130. https://doi.org/10.22610/imbr.v7i2.1146

Kock, N. (2015c). Wheat flour versus rice consumption and vascular diseases: Evidence from the $\begin{array}{lllll}\text { China Study II data. Cliodynamics, 6(2), 130-146. } & \text {. }\end{array}$ https://doi.org/10.21237/C7CLIO6227969

Le Roux, I., \& Bengesi, K. M. K. (2014). Dimensions of entrepreneurial orientation and small and medium enterprise performance in emerging economies. Development Southern Africa. https://doi.org/10.1080/0376835X.2014.913474

Manley, L. (2015). The use of traditional versus e-marketing in SMEs in a developing country: A comparative analysis. Journal of Governance and Regulation. https://doi.org/10.22495/jgr_v4_i4_c1_p7

Öztamur, D., \& Karakadılar, İ. S. (2014). Exploring the Role of Social Media for SMEs: As a New Marketing Strategy Tool for the Firm Performance Perspective. Procedia - Social and Behavioral Sciences. https://doi.org/10.1016/j.sbspro.2014.09.067

Pratono, A. H. (2018). Does firm performance increase with risk-taking behavior under information technological turbulence?: Empirical evidence from Indonesian SMEs. Journal of Risk Finance. https://doi.org/10.1108/JRF-10-2017-0170

USAID. (2019). Theories of Change: High-Growth Small and Medium Enterprise Development. USAID from the American People, 37(May), 1-28. https://www.marketlinks.org/sites/marketlinks.org/files/theories_of_change_-_highgrowth_sme_development_5.13.19.pdf

Wambugu, A., Gichira, R., Wanjau, K. N., \& Mungatu, J. (2015). The Relationship Between Risk Taking and Performance of Small and Medium Agro-Processing Enterprises in Kenya. International Journal of Economics, Commerce and Management United Kingdom.

Yakob, S., B.A.M, H.-S., Yakob, R., \& Raziff, N. (2019). The Effect of Enterprise Risk Management Practice on SME Performance. The southeast Asian Journal of Management. 